\title{
COMPREHENSIVE METHODS OF DIAGNOSIS AND PREVENTION OF POSTPARTUM COMPLICATIONS IN COWS
}

\author{
Abubakari Ibrahim Cawla \\ postgraduate student \\ Sumy National Agrarian University (Sumy, Ukraine) \\ ORCID: 0000-0002-1654-4470 \\ cawlatech@yahoo.com
}

The experiments were conducted during 2018 - 2020 on cows of black-spotted breed in the conditions of LLC "Ryasnyanske" of Krasnopil district of Sumy region.

Cows were aged 4 - 8 years with an average annual milk yield of 2.5 - 3.1 thousand $\mathrm{kg}$ of milk per lactation. Assessment of the postpartum period was performed according to the changes that occurred in the female reproductive system. This took into account not only the general condition of the animals, the nature of the exudate, the size and topography of the uterus, but also the condition of the ovaries, cervix and vagina in rectal and vaginal examinations. Diagnosis of various forms of endometritis was performed based on medical history, clinical and gynecological studies.

For the treatment of cows of the experimental group with postpartum endometritis, they were injected subcutaneously with $10 \mathrm{ml}$ of the drug "Metrisan" in a mixture with $0.5 \%$ solution of novocaine at a rate of 1: 1. The interval between injections was 7-10 days. The frequency depended on the form of endometritis and was 3-5 injections. For the treatment of cows of the control group with postpartum endometritis they used a 10\% solution of ichthyol intrauterinely Injection of $7 \%$ solution of ichthyol into pararectal tissue

In 2018, 2 cows (1.6\%) dropped out for this reason, in 2019 - 4 heads (3.1\%), in $2020-4$ cows (2.8\%). Due to age-related infertility, 1 cow was culled in $2018(0.8 \%), 2$ cows were culled in 2019 (1.3\%), and 2 heads were culled in 2020 (1.4\%). Due to injuries in 2018, 1 cow was discarded (0.8\%), in 20191 cow was culled (0.8\%), in 20201 cow was culled (0.7\%). In 2018, the most common pathology of the postpartum period was vulvo vaginitis $8 \%$, endometritis - $6.5 \%$, artificially acquired infertility - $0.8 \%$. In 2019, 9.8\% of cows had endometritis; vaginitis, vulvitis, cervicitis - $8.3 \%$, artificially acquired infertility was $0.8 \%$. In 2020, endometritis was $17 \%$, vaginitis, vulvitis, cervicitis - $9.2 \%$, artificially acquired infertility was 0.8 . According to the results of the research, the therapeutic efficacy was higher in the experimental group, where the therapy of cows with acute purulent-catarrhal endometritis using the drug sepranol and amoxicillin-150 was used.

The total number of days of infertility in the control group was 125 days, in the experimental - 60 days. In terms of 1 head it is: in the control group - 25 days, in the experimental -12 days. The duration of the period from birth to fertilization in the control group is 55 days, in the experimental group - 42 days.

Key words: cows, causes of infertility, postpartum endometritis, drug "Metrisan"

DOI: https://doi.org/10.32845/bsnau.vet.2020.4.4

Introduction. In the profitability of the dairy industry, an important role belongs to the technology of reproduction, which is considered to be the main biological factor that limiting livestock growth. At the present stage of development of animal husbandry there is no tendency to reducing the frequency of inflammatory processes in the genital system, which complicates the course of postpartum endometritis in animals, and therefore therapy and prevention of obstetric and gynecological diseases is especially relevant for modern obstetrics (Evans, Alexander \& Zeng, Shenming , 2017; Kuzminova, E.V. \& Semenenko, Marina \& Koshchaev, A.G. \& Chernyh, O.Y. \& Turchenko, A.N., 2019; Roman Rudakov, Liliya Khamitova, Anastasiya Metlyakova \& Vyacheslav Milaev, 2020; Pascal, N., OlivierBasole, K., Claired'Andre, H., \& BocklineOmedo, B., 2021; Nyabinwa, P., Kashongwe, O. B., Hirwa, C. D., \& Bebe, B. O. 2020). Numerous data from the literature (Sheldon, I.M., Noakes, D.E., Rycroft, A.N. and Dobson, H., 2002; Potter et al., 2010 T.J. Potter, J. Guitian, J. Fishwick, P.J. Gordon, I.M. Sheldon, 2010) indicate that obstetric and gynecological diseases affect from $10 \%$ to $90 \%$ of cows of the dairy group of farms in different areas of Ukraine.

Among gynecological diseases that lead to infertility, a large role belongs to chronic endometritis (Santos, T. M., Gilbert, R. O., \& Bicalho, R. C., 2011).

Endometritis and sub involution of the uterus cause long-term infertility, decreased meat and dairy productivity, fatness, deterioration of sanitary and technological qualities of milk, lack of a significant number of calves and premature

culling of animals (Ghanem, M. E., Tezuka, E., Devkota, B., Izaike, Y., \& Osawa, T., 2015). Culling and slaughter of infertile animals due to endometritis and ineffective treatment reach 24 $80 \%$ of the number affected by this pathology (Nyabinwa, P., Kashongwe, O. B., Hirwa, C. D., \& Bebe, B. O., 2020).

Prevention of postpartum diseases in uterine cattle and reducing the incidence and death of newborn calves is one of the main problems of veterinary science and practice in the field of non-infectious pathology (Gilbert R. 0., 2016).

One of the urgent problems that need to be solved in veterinary obstetrics is the prevention and treatment of such postpartum diseases in cows as sub involution of the uterus, endometritis, cervical and ovarian diseases (Pascal, N., Olivier Basole, K., Claired' Andre, H., \& Bockline Omedo, B., 2021).

The practice of veterinary medicine in recent years has registered a trend towards the spread of obstetric and gynecological diseases in domestic animals (Potter et al., 2010). For the treatment of females with obstetric and gynecological pathology, more than 50 thousand different compounds are used, of which more than eight thousand are antibacterial in nature (Roman Rudakov, Liliya Khamitova, Anastasiya Metlyakova \& Vyacheslav Milaev, 2020).

Rational complex therapy requires the use of drugs that act on different parts of the pathological process, the basis of which is intrauterine administration rational complex therapy requires the use of drugs that act on various parts of the pathological process, the basis of which is the intrauterine administration of broad-spectrum antibacterial drugs. The use of 
antibiotics in veterinary medicine is a rational and appropriate method that increases the effectiveness of chemotherapy for bacterial complications, especially when using their combinations (Bogado Pascottini, Osvaldo \& Van Schyndel, Sabrina \&Sprícigo, José \& Romulo Carvalho, Murilo \& Mion, Bruna \& Ribeiro, Eduardo \& LeBlanc, Stephen 2020).

\section{Literature Review}

Postpartum endometritis (acute endometritis) inflammation of the uterine mucosa with an acute course, which is accompanied by significant changes in the endometrium and increased activity of healthy or regenerated uterine glands, according to the pathological process and the nature of the secretion of mucus is diagnosed:

- Endometritis catarrhalis characterized by the release of catarrhal exudate;

- Endometritis Catarrhalis et Purulenta, in which the discharge from the genitals are mucous - purulent nature

- Endometritis purulenta - secretion of purulent exudate (Le Blanc S. J., 2014);

According to some authors, the leading role in the pathogenesis of endometritis belongs to the development of autonomic neuroses in the uterus (Dahl-Pedersen, K., Herskin, M. S., Houe, H., \& Thomsen, P. T., 2018). It is established that regardless of the etiology of the inflammatory process (aseptic or infectious), it is accompanied by constant irritation of the nerve endings of sympathetic nerves, which eventually leads to the development of degenerative processes with subsequent accumulation in tissues of deoxidized products and increased activity of hyaluronidase (Gilbert R. O., 2016). At the same time in the places of inflammation there is a violation of blood circulation, this is, the physiological distribution of blood flowing in the tissue of the organ is inhibited due to the so-called microcirculation through arterioles-capillaries-venules (AlBagdadi, F., Eilts, B., \& Richardson, G., 2004). The mechanism of impaired blood microcirculation in the area of inflammation depends on the nature of the primary pathogen and can occur due to vasospasm, thrombosis, as well as - as a consequence of paresis of the venules, the subsequent development of venous stasis. In all cases, regardless of the mechanism of microcirculation, simultaneously with the spasm of small vessels comes the expansion of arterio-venous anastomoses, through which arterial blood, passing the capillary network, enters the venous system. Thus, hypoxia always develops in the area of the inflammatory process, which further complicates the course of the inflammatory reaction (Mohammed, Z. A., Mann, G. E., \& Robinson, R. S., 2019).

Inflammatory processes are usually associated with the penetration of infection, although endometritis is always an infectious process (but not contagious, non-infectious) (de Cássia Bicudo Luana, Oba Eunice, Bicudo Sony Dimas, da Silva Leite Domingos, Siqueira Amanda Keller, de Souza Monobe Marina Mitie, Nogueira Meghi, de Figueire do Pantoja José Carlos, Listoni Fernando José Paganini, Ribeiro Márcio Garcia, 2019). Endometritis occurs due to infection of the genitals of healthy cows with microorganisms that enter the uterine cavity in the postpartum period. The possibility of microbes from the source of infection in the liver, lungs and kidneys is not excluded.

The occurrence of the disease is facilitated by the use of sperm contaminated with opportunistic or pathogenic microorganisms (Yang, H., Zhang, J., Xue, Z. et al., 2020), the wrong choice of insemination time, accompanied by infertility and increases the likelihood of genital infection. Lack of vitamins $A, E, D, B$, minerals, especially trace elements $\mathrm{Co}, \mathrm{Zn}, \mathrm{Cu}$ complicates the course of endometritis. Reducing the body's resistance, keeping cows in warm, stuffy rooms, lack of exercise, leads to the development of inflammatory processes in the uterus (Hasan, W. I., \& Mustafa, K. N. S., 2020).

Specific diseases, as well as unqualified unsystematic treatment of inflammatory processes with glucocorticoid hormones and other immunosuppressant's poses a real threat to the transition of inflammation into chronic and latent forms (Schlegl, Roland \& Drillich, Marc \& Ballas, Panagiotis \& Reinländer, Ulrike \& Iwersen, Michael \& Baumgartner, Walter \& Ehling-Schulz, Monika \& Wagener, Karen, 2020). According to the authors (Santos, T. M., Gilbert, R. O., \& Bicalho, R. C. 2011), subacute and chronic endometritis occurs 14 days after calving, although according to other authors, 2-3 weeks after birth, acute endometritis is registered. In the presence of favorable conditions, the inflammatory process can occur even under the influence of low-pathogenic microbes that have entered the uterus. Sometimes it develops due to the activation of the micro flora that takes place in the uterine cavity (autoinfection) (Yang, H., Zhang, J., Xue, Z. et al, 2020).

Some authors see a significant role in the pathogenesis of postpartum infection of immune disorders, which leads to a decrease in anti-infective resistance of the organism, even to opportunistic pathogens and auto flora (Mohammed, Z. A., Mann, G. E., \& Robinson, R. S. 2019).

In the acute course of the disease, the general condition does not differ significantly from the norm, but for several days periodically or constantly from the genitals secreted mucopurulent exudate. There is a development of persistent changes in the mucous membrane, muscular and serous layers of the uterus, and these changes are often irreversible (DahlPedersen, K., Herskin, M. S., Houe, H., \& Thomsen, P. T., 2018). The cervical canal is slightly open. There is cyanosis and redness of the mucous membrane of the vaginal part of the cervix. At rectal research increase in a uterus, lack of its contractile function, pain and thickening of separate sites of walls, horns and a body of body are noted. Damaged endometrium does not produce prostaglandins, which causes the persistence of corpora lutea with the cessation of cyclic activity (Al-Bagdadi, F., Eilts, B., \& Richardson, G., 2004).Changes in the mucous membrane in the form of thickening, loosening, erosions and ulcers. From the uterine glands are formed cysts with chicken egg, some groups with hyperplasia (Mohammed, Z. A., Mann, G. E., \& Robinson, R. S., 2019). Prolonged course of chronic endometritis causes desquamation of the integumentary epithelium and the disappearance of caruncles. At alteration the uterus reminds a thin-walled bag which hangs down in an abdominal cavity. The appearance of signs characteristic of chronic endometritis is possible after the next insemination, which is a stimulus to the transition of the inflammatory process from the subclinical phase to the clinical manifestation. After incomplete treatment, the disease seems to subside, and after 3 - 4 weeks runs in the form of acute and then chronic inflammatory processes of this organ (Bogado Pascottini, Osvaldo \& Van Schyndel, Sabrina \&Sprícigo, José \& Romulo Carvalho, Murilo \& Mion, Bruna \& Ribeiro, Eduardo \& LeBlanc, Stephen, 2020).

\subsection{Diagnosis.}


The transition from acute to chronic inflammation is very difficult to diagnose in time by clinical signs and even by immunological analysis. The effectiveness of the diagnosis of chronic inflammation is insufficient, because it is carried out without taking into account the pathogenesis of the disease (Dubuc, J., Duffield, T. F., Leslie, K. E., Walton, J. S., \& LeBlanc, S. J., 2010). The diagnosis is made comprehensively on the basis of anamnestic data, clinical and obstetric examination of the animal and laboratory tests. At clearly expressed clinical signs of endometritis diagnosis is not difficult. In the absence of clinical signs, an endometrial biopsy is performed, followed by histological examination of samples (Mohammed, Z. A., Mann, G. E., \& Robinson, R. S., 2019). Many different methods have been proposed for the diagnosis of latent endometritis and various data on their effectiveness have been obtained.

In practice, the diagnosis is made visually, that is evaluate the mucus taken from the cow during heat for the presence of small flakes of manure, discoloration, but this condition is not found in all sick animals. Laboratory methods allow the most objective judgment of pathological changes that occur in the female reproductive system, but they are expensive, time-conTotaling and economically unprofitable for practical use (Brewer, Amy \& Cormican, Paul \& Lim, Joseph \& Chapwanya, Aspinas \& O'Farrelly, Cliona \& Meade, Kieran, 2020).

The bacteriological method is not always reliable, because the uterine cavity may be free of microbes. The most accurate and easily accessible method is a bioassay. The condition of the endometrium can be judged by examination of the smear - imprint on the cytological picture (Al-Bagdadi, F., Eilts, B., \& Richardson, G., 2004).

In subclinical endometritis, histamine can be detected in the urine of patients using a slap test (Brewer, Amy \& Cormican, Paul \& Lim, Joseph \& Chapwanya, Aspinas \& O'Farrelly, Cliona $\&$ Meade, Kieran, 2020).

A fairly accurate method of diagnosing subclinical endometritis is the Fol's method, which allows you to detect sulfur-containing amino acids in the leaky mucus (Barański, W., Podhalicz-Dzięgielewska, M., Zduńczyk, S., \&Janowski, T., 2012).

\subsection{Treatment}

Based on the above, most modern authors (Evans, Alexander \& Zeng, Shenming., 2017; Roman Rudakov, Liliya Khamitova, Anastasiya Metlyakova \& Vyacheslav Milaev , 2020) Sheldon, I.M., Noakes, D.E., Rycroft, A.N. and Dobson, H., 2002; Gilbert R. O., 2016; Mohammed, Z. A., Mann, G. E., \& Robinson, R. S. 2019; Hasan, W. I., \& Mustafa, K. N. S., 2020) in the treatment of cows with postpartum endometritis recognize the most optimal tactics of a veterinarian, which includes the following main positions:

1. Increasing the body's defenses.

2. Restoration of contractile ability of a myometrium.

3. Removal of exudate containing microbes, toxins, tissue breakdown products and suppression of the vital micro flora in the uterine cavity.

4. Stimulation of regenerative processes in the endometrium

To achieve these goals, non-specific, pathogenetic and symptomatic therapies are recommended, aimed at both the pathogenic focus and the normalization of body function as a whole.

It is well known that the use of even the most effective therapeutic agents against the background of low resistance does not give a positive result. Therefore, to increase the body's resistance to cows in gynecological diseases, modern clinicians recommend various methods among which the leading place belongs to the works on tissue therapy (Hasan, W. I., \& Mustafa, K. N. S. 2020; Masoumi, Reza \&Badiei, A \&Mousakhani, F \&Dirandeh, Essa\&Zhandi, Mahdi \&Stear, Michael, 2018).

Currently, oil-based intrauterine devices are widely used, and some authors point to the use of bacterial drugs (Doderlein bacillus culture, spore bacteria, lactobacilli), which are antagonists of pathogenic uterine micro flora (Sheldon, I.M., Noakes, D.E., Rycroft, A.N. and Dobson, H. 2002).

For the treatment of cows with chronic endometritis, offer drugs that have long-term antimicrobial action (Elsayed, Doaa H., El-Azzazi, Fakhri E., Mahmoud, Yasmina K., Dessouki, Sherif M., \&Ahmed, Eman A., 2020). Using antibacterial drugs, we warn of generalization (spread to surrounding tissues) of inflammation, which is currently the prevention of sepsis (Le Blanc S. J., 2014). Drugs injected into the uterine cavity should be indifferent to the internal environment of the uterus, replacing it with properties. It is especially important that they do not destroy or shrink the mucin of the uterus (Al-Bagdadi, F., Eilts, B., \& Richardson, G., 2004).

Thus, according to many authors (Le Blanc S. J. 2014), antimicrobial therapy is not always effective enough due to the rapid habituation of microorganisms to drugs, stimulating the action of some of them on the development of pathogenic fungi, as well as their suppression of natural mechanisms of local and general antimicrobial protection. Although, as noted by other authors (Yang, H., Zhang, J., Xue, Z. et al. 2020), Antibiotics in comparison with other means give a better effect in many common animal diseases, The use of antibiotics promotes the development of resistance of microorganisms - this fact is indisputable, although there is a so-called "threshold" of antibiotic use, below which the selection of antibiotic-resistant bacteria does not occur, depending on the number of antibiotics, their dose and duration (Ghanem, M. E., Tezuka, E., Devkota, B., Izaike, Y., \& Osawa, T., 2015). The exclusion of antibiotics from use does not always help reduce the number of resistant and return sensitive strains, oscillating microbes pass protection to other families (Le Blanc S. J., 2014). Absence in some cases of a positive result can be observed at late use of these means [13]. In the formation of stable associations of pathogens to combat them, it is necessary to use complex antibiotics (Yang, H., Zhang, J., Xue, Z. et al. 2020).

Some authors (Mohammed, Z. A., Mann, G. E., \& Robinson, R. S., 2019) claim that the use of antibiotics in gynecological diseases completely eliminates the use of milk for food purposes, and even after pasteurization, it is suitable only for animal feed. Other authors believe (Dubuc, J., Duffield, T. F., Leslie, K. E., Walton, J. S., \& LeBlanc, S. J., 2010) that the uterine wall has poor permeability to macromolecular structures, which include antibiotics. Thus, after intrauterine infusion of $3 \mathrm{~g}$ of tetracycline, the final amount in milk after 84 hours was less than $100 \mu \mathrm{g} / \mathrm{kg}$. The lowest level of neurotoxicity that does not cause a visible effect of toxicological action is $100 \mu \mathrm{g} / \mathrm{kg}$ of animal weight per day, and this permissible daily use provides the necessary effectiveness of treatment (de Cássia Bicudo 
Luana, Oba Eunice, Bicudo Sony Dimas, da Silva Leite Domingos, Siqueira Amanda Keller, de Souza Monobe Marina Mitie, Nogueira Meghi, de Figueire do Pantoja José Carlos, Listoni Fernando José Paganini, Ribeiro Márcio Garcia 2019). Therefore, the accumulation of pharmazone and tetracycline in the tissues and organs of animals treated, as well as their excretion in milk is relatively small.

Aims.

The main purpose of the research is to study the effectiveness of complex schemes of therapy of cows in acute postpartum purulent-catarrhal endometritis, in particular with the use of immunomodulatory drugs with simultaneous intrauterine administration of gel-based antibiotics.

To achieve this goal, the following tasks were set:

$\checkmark$ to study the reasons for the spread of obstetric pathology of cows in farms of Luhansk region, in particular the spread of chronic endometritis;

$\checkmark$ to conduct a comparative evaluation of the therapeutic efficacy of intrauterine use of gel-based antibiotics tetracycline and tilane and iodine bismuth sulphonamide emulsion in chronic endometritis in cows and to study the residual amount of antibiotics in milk after a course of antibiotic therapy.

$\checkmark$ determine the cost-effectiveness of the proposed methods of treatment of cows with postpartum endometritis

Materials and Methods

The experiments were conducted during 2018 - 2020 on cows of black-spotted breed in the conditions of LLC "Ryasnyanske" of Krasnopil district of Totaly region.

Cows were aged $4-8$ years with an average annual milk yield of 2.5 - 3.1 thousand $\mathrm{kg}$ of milk per lactation.

Feeding rations of control and experimental groups of animals were not balanced or on individual indicators in accordance with feeding norms. Assessment of the postpartum period was performed according to the changes that occurred in the female reproductive system. This took into account not only the general condition of the animals, the nature of the exudate, the size and topography of the uterus, but also the condition of the ovaries, cervix and vagina in rectal and vaginal examinations.

At rectal research paid attention also to the general reaction of an animal.

Diagnosis of various forms of endometritis was performed based on medical history, clinical and gynecological studies.

For the treatment of cows of the experimental group with postpartum endometritis, they were injected subcutaneously with $10 \mathrm{ml}$ of the drug "Metrisan" in a mixture with $0.5 \%$ solution of novocaine at a rate of $1: 1$. The interval between injections was 7-10 days. The frequency depended on the form of endometritis and was 3-5 injections (Tab. 1).

For the treatment of cows of the control group with postpartum endometritis they used a $10 \%$ solution of ichthyol intrauterine ly Injection of $7 \%$ solution of ichthyol into pararectal tissue

The effectiveness of treatment was determined by the timing of clinical recovery of animals.

The gynecological examination consisted of external and internal examination. In the study by examination and palpation determined the condition of the abdominal wall, udder, the configuration of the root of the tail, the condition of the pelvic ligaments, vulva, withered crusts, the presence of exudate, its quantity, consistency and color.

Table 1

Scheme of treatment of cows with postpartum endometritis

\begin{tabular}{|l|l|}
\hline \multicolumn{1}{|c|}{ A group of animals } & \multicolumn{1}{|c|}{ Scheme } \\
\hline Experimental $(n=10)$ & $\begin{array}{l}\text { Candles with rivanol intrauterine } \\
\text { Metrisan injections subcutaneously } 10 \mathrm{ml}\end{array}$ \\
\hline Control $(n=10)$ & $\begin{array}{l}10 \% \text { solution of ichthyol intrauterine } \\
\text { Injection of } 7 \% \text { solution of ichthyol into pararectal tissue }\end{array}$ \\
\hline
\end{tabular}

Vaginal and rectal examination was performed on prerecorded animals in the stall. When conducting a vaginal examination, the animal was placed in the direction of the daylight source. A pre-boiled vaginal mirror was used for work. The vagina, vaginal part of the cervix and anterior vagina were examined, paying attention to the color change of the mucous membrane, violation of its integrity: swelling of the cervical mucosa, overlays, scars, adhesions, cervical gaps, exudate from the uterus.

The cervix, body, uterine horns, ovaries, pelvic bones, and uterine mesentery were palpated rectally through the rectum. Examining the cervix, they paid attention to its location, size, consistency, mobility, pain, curvature. Palpation of the uterus determined the location, contractility, size, consistency and configuration of the horns, pain, presence, nature and number of discharges. Ovaries investigated, determining their shape, size, consistency, surface nature, mobility and soreness.

At rectal research paid attention also to the general reaction of an animal.

Biochemical studies to determine the content in serum of total protein, seromucoids, glucose and triglycerides, sodium, potassium, calcium and phosphorus and alkaline phosphatase activity were performed in the laboratory of the Department of Surgery of SNAU.

Results

The reason for rejection was the loss of milk productivity. For this reason, 4 cows $(2.8 \%)$ were culled in 2018, 3 cows $(2.3 \%)$ in 2019 , and 4 cows $(2.8 \%)$ in 2020.

According to the number of culls of cows there is symptomatic infertility. In 2018, 2 cows (1.6\%) dropped out for this reason, in 2019 - 4 heads (3.1\%), in $2020-4$ cows (2.8\%). Due to age-related infertility, 1 cow was culled in $2018(0.8 \%), 2$ cows were culled in 2019 (1.3\%), and 2 heads were culled in $2020(1.4 \%)$. Due to injuries in 2018, 1 cow was discarded $(0.8 \%)$, in 20191 cow was culled $(0.8 \%)$, in 20201 cow was culled $(0.7 \%)($ Tab.2) 
Table 2.

The reasons for culling cows on the farm

\begin{tabular}{|c|c|c|c|c|c|c|}
\hline \multirow{2}{*}{ Indicator } & \multicolumn{2}{|c|}{2018} & \multicolumn{2}{|c|}{2019} & \multicolumn{2}{|c|}{2020} \\
\hline & heads & $\%$ & heads & $\%$ & heads & $\%$ \\
\hline All cows left & 6 & 4,8 & 9 & 6,8 & 8 & 5,4 \\
\hline Hypogalactia and breast disease & 4 & 3,2 & 3 & 2,3 & 4 & 2,8 \\
\hline Age rejection & 1 & 0,8 & 2 & 1,3 & 2 & 1,4 \\
\hline Injuries & 1 & 0,8 & 1 & 0,8 & 1 & 0,7 \\
\hline Symptomatic infertility & 2 & 1,6 & 4 & 3,1 & 4 & 2,8 \\
\hline
\end{tabular}

On average, 23 animals (5.4\%) dropped out in 3 years, of which 11 heads (2.8\%), symptomatic infertility - 11 heads $(2.8 \%)$, age-related infertility - 5 cows (due to loss of milk productivity). $1.3 \%$ ), injuries -3 heads $(0.8 \%)$.

Prevalence of pathological births and diseases of the postpartum period

During this period from 2018 to 2020 the number of births per herd was 277 , including in $2018-89$, in $2019-92$, in 2020 - 96. The number of normal physiological births in this period was $313(82.7 \%)$, the number of pathological births - 59 cases $(15.4 \%)$.

The causes of pathological birth in 2018 in this farm were: weakness of contractions and attempts - 15 cases (12\%), the wrong relationship between the fetus and the birth canal - 2 cases $(1.6 \%)$, delayed litter -13 cases $(10.5 \%$ of total number of births)

In 2019, the weakness of contractions and attempts 13 cases $(9.8 \%)$, the wrong relationship between the fetus and the birth canal - 1 case $(0.8 \%)$, manure delay - 8 cases $(6 \%)$ (Tab. 3.).

The main causes of pathological birth in the economy

Table 3.

\begin{tabular}{|c|c|c|c|c|c|c|c|}
\hline \multirow{2}{*}{ Years } & \multirow{2}{*}{ Total cows } & \multicolumn{2}{|c|}{ Weak contractions and attempts } & $\begin{array}{c}\text { Incorrect relationship between the fetus } \\
\text { and the birth canal }\end{array}$ & \multicolumn{2}{c|}{ Manure delay } \\
\cline { 3 - 8 } & & Total & $\%$ & Total & $\%$ & Total & $\%$ \\
\hline 2018 & 124 & 15 & 12 & 2 & 1,6 & 13 & 10,5 \\
2019 & 133 & 13 & 9,8 & 1 & 0,8 & 8 & 6 \\
2020 & 141 & 10 & 7 & 1 & 0,7 & 4 & 2,8 \\
\hline Total & 398 & 38 & 9,5 & 4 & 1 & 25 & 6,3 \\
\hline
\end{tabular}

In 2020, the number of cases of weakness of contractions and attempts - 10 cases (7\%), the wrong relationship between the fetus and the birth canal - 1 case $(0.7 \%)$, delayed litter -4 cases $(2.8 \%)$.

In the first place for the last 3 years among the causes of pathological birth is registered weakness of contractions and attempts - 38 cases, $9.5 \%$; then there is a delay of manure - 25 cases, $6.3 \%$ of the total number of births for 3 years and the wrong relationship between the fetus and birth canal - 4 cases, $1 \%$. The most important among the pathologies of the postpartum period are endometritis, vaginitis, vulvitis, cervicitis and other gynecological diseases.

Study of indicators of postpartum pathology of cows,
Analyzing this statistical report and the above material, we can conclude that the most common cause of culling was the pathology of the postpartum period, which once again indicated the relevance of our chosen topic and the feasibility of research in this area.

The following conclusions can be drawn from the table. In 2018, the most common pathology of the postpartum period was vulvo vaginitis $8 \%$, endometritis $-6.5 \%$, artificially acquired infertility $-0.8 \%$. In $2019,9.8 \%$ of cows had endometritis; vaginitis, vulvitis, cervicitis $-8.3 \%$, artificially acquired infertility was $0.8 \%$. In 2020 , endometritis was $17 \%$, vaginitis, vulvitis, cervicitis $-9.2 \%$, artificially acquired infertility was 0.8 (Tab. 4.)

Dynamics of postpartum pathology of cows

\begin{tabular}{|l|l|l|l|l|l|l|l|l|}
\hline \multirow{2}{*}{\multicolumn{1}{|c|}{ Types of pathology }} & \multicolumn{2}{|c|}{ year 2018 } & \multicolumn{2}{c|}{ year 2019 } & \multicolumn{2}{c|}{ year 2020 } & \multicolumn{2}{c|}{ Total } \\
\cline { 2 - 10 } & Total of cows & \multicolumn{2}{|c|}{ Total of cows } & $\%$ & Total of cows & $\%$ & Total of cows & \% \\
\hline Normal course & 105 & 84,6 & 109 & 81,9 & 110 & 78,1 & 324 & 93 \\
\hline Pathological course & 19 & 15,3 & 24 & 18,1 & 31 & 21,9 & 74 & 22,8 \\
\hline Postpartum endometritis & 8 & 6,5 & 13 & 9,8 & 17 & 12 & 38 & 9,5 \\
\hline Vaginitis, vulvitis, Cervicitis & 10 & 8 & 11 & 8,3 & 13 & 9,2 & 34 & 8,5 \\
\hline Artificially acquired barrenness & 1 & 0,8 & 1 & 0,8 & 1 & 0,8 & 3 & 0,8 \\
\hline
\end{tabular}

The study was performed on two groups of animals control and experimental 5 heads in each.

Animals of the first group (control group) used uterine lavage with an Esmarch mug $0.1 \%$ aqueous solution of potassium permanganate - for 1, 2, 3, 4, 5 days for 2.5 liters. Furazolidone stick - from 1 to 5 days for 6 pieces, oxytocin - for $1,3,5,7,9$, day 40 Units. Furazolidone rods have an antiseptic effect. Oxytocin activates the contraction of uterine smooth muscle and helps remove exudate. Tetravit - for 1 and 10 days for $15 \mathrm{ml}$. Tetravit compensates for the lack of vitamins in animals. Vitamin A, D3, E. Flushing the uterus with an Esmarch mug $0.1 \%$ aqueous solution of potassium permanganate - for 1 , $2,3,4,5$ days for 2.5 liters. Potassium permanganate is an antiseptic. Amoxicillin twice a day at a dose of $40 \mathrm{ml}$, this is an antibiotic. The drug completely blocks the growth and development of bacteria.

Animals of the second group (experimental) were treated with the drug sepranol - intrauterine 2 tablets for 5 days, amoxicillin 150 - intramuscularly $50 \mathrm{ml}$. once. Sepranol has a broad antibacterial spectrum of action against most grampositive and gram-negative bacteria, protozoa and fungi, as well as provides anti-inflammatory action, improves proliferative 
processes in the genitals; propranolol hydrochloride - stimulates the activity of the uterus and is a beta-blocker adrenoceptor biometrics. Amoxicillin is a semi-synthetic antibiotic and has a broad spectrum of antimicrobial activity. The mechanism of action of amoxicillin is to disrupt the synthesis of mucopeptide, which is part of the cell wall of microorganisms, by inhibiting the enzymes transpeptidase and carboxypeptidase, which leads to osmotic imbalance and destruction of the bacterial cell.

Table 5.

Scheme of the experiment

\begin{tabular}{|l|l|l|l|}
\hline \multicolumn{1}{|c|}{ Group } & $\begin{array}{c}\text { Number of } \\
\text { heads }\end{array}$ & \multicolumn{1}{c|}{ Therapeutic drugs } & $\begin{array}{c}\text { Number of days of } \\
\text { the experiment }\end{array}$ \\
\hline Control & 15 & $\begin{array}{l}\text { Potassium permagnate 2.5 liters, invaginally for the first 5 days. } \\
\text { Furazolidone sticks 6 pcs. Internally - uterine, the first 5 days. } \\
\text { Oxytocin 40 U, intramuscularly, 1,3,5,7,9. } \\
\text { Tetravit 15 ml., Intramuscularly, 1-10. } \\
\text { Bicillin 3, intramuscularly 4.5 million IU. On the 1st day. }\end{array}$ & 10 \\
\hline Experimental & 15 & $\begin{array}{l}\text { Sepranol intrauterine, 2 tablets. The first } 5 \text { days. } \\
\text { Amoxicillin 150 intramuscularly, in a dose of 50 ml, on the first day. }\end{array}$ & 5 \\
\hline
\end{tabular}

The results of the study conducted in the farm "Dubrava" $\mid$ region, it was found that the proposed therapy was effective in located in the village of Ochkine Seredino-Bud district of Totaly $\mid$ both the experimental and control groups (Tab.6).

Table 6

The effectiveness of methods of treatment of cows with acute postpartum purulent-catarrhal endometritis

\begin{tabular}{|c|c|c|c|c|c|c|c|}
\hline \multirow{2}{*}{ A group of animals } & \multirow{2}{*}{ Number of animals } & \multirow{2}{*}{$\begin{array}{c}\text { Duration of } \\
\text { treatment, days }\end{array}$} & \multirow{2}{*}{ Recovered } & \multirow{2}{*}{$\begin{array}{l}\text { Fertilized after } \\
\text { birth }\end{array}$} & \multicolumn{2}{|c|}{ Number of days of infertility } & \multirow{2}{*}{$\begin{array}{c}\text { Duration from birth to } \\
\text { fertilization }\end{array}$} \\
\hline & & & & & in the group & for 1 head & \\
\hline Control & 15 & 10 & 4 & 4 & 125 & 25 & 55 \\
\hline Experimental & 15 & 5 & 5 & 5 & 60 & 12 & 42 \\
\hline
\end{tabular}

However, according to the results of the studies, the therapeutic efficacy was higher in the experimental group, where the therapy of cows with acute purulent-catarrhal endometritis using the drug sepranol and amoxicillin 150 was used.

The total number of days of infertility in the control group was 125 days, in the experimental - 60 days. In terms of 1 head it is: in the control group - 25 days, in the experimental -12 days.

The duration of the period from birth to fertilization in the control group is 55 days, in the experimental group - 42 days.

Discussion of the results of research

Acute postpartum purulent-catarrhal endometritis is one of the most common and dangerous diseases of cows, which brings huge economic losses to the economy. Diseases of the uterus not only negatively affect fertility, but also reduce all types of animal productivity. The disease begins to develop on the 5th - 6th day after birth in the form of altered lochia from the uterus.

The pathological process in endometritis is localized in the mucous membrane and connective tissue. Once in the uterus, microbes irritate the tissues with the products of their vital activity. As a result of the action of microbes and their toxins, inflammation occurs, the spread of which depends on the virulence of microbes, the resistance of uterine tissues and its response to pathogenic factors.

The inflammatory process begins to develop with redness and swelling of the tissues. The vessels of the uterus dilate and overflow with blood, increased transudation leads to the development of edema. In the stage of hyperemia, the activity of oxidative processes in the tissues of the uterus increases sharply.

The disease occurs as a result of injury and infection of the uterus during birth, retention of manure, abortion, etc. Favorable factors are important: poor feeding, the predominance of acidic foods, mineral and vitamin deficiency of cows.

In the pathology of development for, prophylactic and therapeutic purposes use antibacterial and anti-inflammatory drugs. In the process of laboratory, clinical and industrial studies, the drugs have proven to be low-toxic and highly effective in diseases of acute postpartum purulent-catarrhal endometritis.

As a result of research, it was found that the use of the drug sepranol and amoxicillin-150 better treats and prevents the development of furazolidone sticks, tetravit.

\section{Discussions}

The transition from acute to chronic inflammation is very difficult to diagnose in time by clinical signs and even by immunological analysis (Hasan, W. I., \& Mustafa, K. N. S. (2020). Many authors (Barański, W., Podhalicz-Dziegielewska, M., Zduńczyk, S., \&Janowski, T. (2012) note that sub acute and chronic endometritis occurs in 14 days after calving, although according to other authors (Masoumi, Reza \&Badiei, A \&Mousakhani, F \&Dirandeh, Essa\&Zhandi, Mahdi \&Stear, Michael. (2018), acute endometritis is registered 2-3 weeks after calving. Timely veterinary care for a sick cow helps to reduce the service period, accelerate the fertilization of cows, reduces the duration of treatment and funds for therapeutic agents (Hasan, W. I., \& Mustafa, K. N. S. (2020)).

Unbalanced diet in all respects, low quality of prepared feed, lack of mineral and vitamin supplements in the diet cause a decrease in blood levels of vital substances in all respects, especially carotene, which helps to suppress non-specific indicators of immunobiological protection and activation of micro florauterus. The main etiological factor in the occurrence of chronic endometritis in cows are pathogenic and opportunistic microorganisms, which, acting on the body together, enhance their virulence properties and cause a pathological process (Dahl-Pedersen, K., Herskin, M. S., Houe, H., \& Thomsen, P. T. (2018)).

Given the participation of blood in physiological reactions that cause changes in cellular and humoral immune factors, depending on environmental conditions and pathology (chronic endometritis) (Elsayed, Doaa H., El-Azzazi, Fakhri E., Mahmoud, Yasmina K., Dessouki, Sherif M., \&Ahmed, Eman A.), the morpho-biochemical and immunological parameters of 
clinically healthy and endometritis cows were determined. Studies of morphological composition included counting the number of erythrocytes, leukocytes, leukogram output, and biochemical analysis of blood - determining the amount of hemoglobin, total protein and its fractions.

In sick cows there is a significant decrease in the content of erythrocytes and leukocytes. The appearance in the blood of animals with endometritis, basophils and young neutrophils, as well as an increase in the number of rod and segmental neutrophils indicates neutrophilia with a simple regenerative shift of the nucleus to the left, indicating the presence of purulent inflammation in the body (Ghanem, M. E., Tezuka, E., Sasaki, K., Takahashi, M., Yamagishi, N., Izaike, Y., \&Osawa, T. (2016)). This is due to the fact that the main function of neutrophils is their participation in protecting the body from infectious and toxic effects (Stojkov, Yanne\&Keyserlingk, Marina\&Duffield, T. \&Fraser, D.. (2020)). Neutrophils - the first protective barrier against the penetration of microorganisms into the internal environment of the body; they are able to function in inflammation not only as phagocytes, but also as a "secretory gland", maintaining homeostasis under conditions of infection by agents of various natures (Barański, W., Podhalicz-Dzięgielewska, M., Zduńczyk, S., \&Janowski, T. (2012)).

Among the biochemical parameters we noted some differences. The amount of total protein, albumin and hemoglobin in the blood of sick cows was significantly reduced compared to clinically healthy animals. Hypoalbuminemia leads to metabolic disorders between the blood and the interstitial space, as well as to the disruption of the transport of hormones, vitamins and minerals (Ghanem, M. E., Tezuka, E., Sasaki, K., Takahashi, M., Yamagishi, N., Izaike, Y., \&Osawa, T. (2016)). The increase in all fractions of globulins, in particular -globulins in chronic inflammation, is due to their participation in the defense mechanisms of the sick animal, and the increase in - globulins - due to the presence of lipoproteins in this fraction. Almost the same content of -globulins, which are mainly immunoglobulins, in our opinion, is characterized by the fact that the intensification of immunological processes was observed in the acute phase of inflammation, which is not typical in the transition of this process to chronic. All this led to a significant decrease in the protein ratio, that is, to dysproteinemia.

That is, analyzing the obtained data of clinically healthy and patients with chronic purulent-catarrhal endometritis, we conclude that in the body of patients there is a complex of immunological and morphobiochemical changes that cause the chronic course. These processes are associated with the development of a secondary immunodeficiency condition relative to the suppressor variant, caused by both the immunogenicity of microorganisms and their toxins, and morphological changes in tissue in the area of inflammation (Semenov, V \& Baimukanov, D \& Tyurin, V \& Kuznetsov, A \& Tsarevsky, I \& Nikitin, D \& Efimova, I. (2020)).

\section{Conclusions}

1.The fertilization rate of cows over the past three years has tended to decrease due to a decrease in the percentage of animals that gave birth to twins and an increase in such indicators as stillbirth and abortion of non-infectious origin; on average, this figure for the last three years is $91.73 \%$.

2. The infertility of cows on the farm over the past four years has a tendency to increase and averages $22.9 \%$, and its main causes are infertility $(74 \%)$, obesity and depletion of $13 \%$.

3.Cow shortage occurs mainly due to injuries of general origin $0.68 \%$ and infertility $47.62 \%$, age $-9.18 \%$ and due to low productivity $-38.44 \%$.

4.The best effect in the treatment of animals with delayed manure was found when using candles with rivanol intrauterine and injections of "Metrisan" subcutaneously $10 \mathrm{ml}$.

\section{Reference}

1. Al-Bagdadi, F., Eilts, B., \& Richardson, G. (2004). Scanning Electron Microscopy of the Endometrium of Mares Infused with Gentamicin. Microscopy and Microanalysis, 10(2), 280-285. https://doi.org/doi:10.1017/S1431927604040115

2. Barański, W., Podhalicz-Dzięgielewska, M., Zduńczyk, S., \&Janowski, T. (2012). The diagnosis and prevalence of subclinical endometritis in cows evaluated by different cytologic thresholds. Theriogenology, 78(9), 1939-1947. https://doi.org/10.1016/j.

3. Bogado Pascottini, Osvaldo \& Van Schyndel, Sabrina \&Sprícigo, José \& Romulo Carvalho, Murilo \& Mion, Bruna \& Ribeiro, Eduardo \& LeBlanc, Stephen. (2020). Effect of anti-inflammatory treatment on systemic inflammation, immune function, and endometrial health in postpartum dairy cows. Scientific Reports. https://doi.org/10.10.1038/s41598-020-62103-x.

4. Brewer, Amy \& Cormican, Paul \& Lim, Joseph \& Chapwanya, Aspinas \& O'Farrelly, Cliona \& Meade, Kieran. (2020). Qualitative and quantitative diferences in endometrial infammatory gene expression precede the development of bovine uterine disease. Scientific Reports. https://doi.org/10.18.10.1038/s41598-020-75104-7.

5. Dahl-Pedersen, K., Herskin, M. S., Houe, H., \& Thomsen, P. T. (2018). Risk Factors for Deterioration of the Clinical Condition of Cull Dairy Cows During Transport to Slaughter. Frontiers in veterinary science, 5, 297. https://doi.org/10.3389/fvets.2018.00297

6. de Cássia Bicudo Luana, Oba Eunice, Bicudo Sony Dimas, da Silva Leite Domingos, Siqueira Amanda Keller, de Souza Monobe Marina Mitie, Nogueira Meghi, de Figueire do Pantoja José Carlos, Listoni Fernando José Paganini, Ribeiro Márcio Garcia (2019) Virulence factors and phylogenetic group profile of uterine Escherichia coli in early postpartum of high-producingdairy cows. Animal Production Science 59, 1898-1905.https://doi.org/10.1071/AN17729

7. Dubuc, J., Duffield, T. F., Leslie, K. E., Walton, J. S., \& LeBlanc, S. J. (2010). Definitions and diagnosis of postpartum endometritis in dairy cows. Journal of dairy science, 93(11), 5225-5233. https://doi.org/10.3168/jds.2010-3428

8. Elsayed, Doaa H., El-Azzazi, Fakhri E., Mahmoud, Yasmina K., Dessouki, Sherif M., \&Ahmed, Eman A.. (2020). Subclinical endometritis and postpartum ovarianre Total option in respectto TNF-a, IL-8 and CRP in Egyptian buffaloes. Animal Reproduction, 17(1), e20190027. Epub February 07, 2020.https://doi.org/10.21451/1984-3143-ar2019-0027

9. Evans, Alexander \& Zeng, Shenming. (2017). Causes, prevention and management of infertility in dairy cows. 
https://doi.org/10.19103/AS.2016.0006.20.

10. Ghanem, M. E., Tezuka, E., Devkota, B., Izaike, Y., \& Osawa, T. (2015). Persistence of uterine bacterial infection, and its association swith endometritis and ovarian function in postpartum dairy cows. The Journal of reproduction and development, 61(1), 54-60. https://doi.org/10.1262/ird.2014-051

11. Ghanem, M. E., Tezuka, E., Sasaki, K., Takahashi, M., Yamagishi, N., Izaike, Y., \&Osawa, T. (2016). Correlation of blood metabolitec on centrations and body conditions cores with persistent postpartum uterine bacterial infection in dairy cows. The Journal of reproduction and development, 62(5), 457-463. https://doi.org/10.1262/jrd.2015-103

12. Gilbert R. O. (2016). Management of Reproductive Disease in Dairy Cows. The Veterinary clinics of North America. Food animal practice, 32(2), 387-410. https://doi.org/10.1016/j.cvfa.2016.01.009

13. Hasan, W. I., \& Mustafa, K. N. S. (2020). Effect of vitamin e and selenium injectionon some physiological characteristics and biochemical parameters in localram lamb. Journal of Duhok University, 23(2), 34-43. Retrieved from https://journal.uod.ac/index.php/uodjournal/article/view/854

14. Kuzminova, E.V. \& Semenenko, Marina \& Koshchaev, A.G. \& Chernyh, O.Y. \& Turchenko, A.N..(2019). Pharmacological prevention of obstetric and gynecological diseases in cows.Dusunen Adam. 10. 608-612.

15. Le Blanc S. J. (2014). Reproductive tract inflammatory disease in postpartum dairy cows. Animal: aninternational journal of animalbioscience, 8 Suppl 1, 54-63. https://doi.org/10.1017/S1751731114000524

16. Masoumi, Reza \&Badiei, A \&Mousakhani, F \&Dirandeh, Essa\&Zhandi, Mahdi \&Stear, Michael. (2018). Quantification of the uterine involution and dimensions, hormonal response and reproductive performance of pyometric and healthy dairy cows treated with Dinoprost. South African Journal of Animal Science.48. https://doi.org/10.4314/sajas.v48i2.3.

17. Mohammed, Z. A., Mann, G. E., \& Robinson, R. S. (2019). Impact of endometritis on postpartum ovarian cyclicity in dairy cows. Veterinary journal (London, England : 1997), 248, 8-13. https://doi.org/10.1016/j.tvjl.2019.03.008

18. Nyabinwa, P., Kashongwe, O. B., Hirwa, C. D., \& Bebe, B. O. (2020). Perception of farmers about endometritis prevention and control measures for zero-grazed dairy cows on small holder farms in Rwanda. BMC veterinary research, 16(1), 175. https://doi.org/10.1186/s12917-020-02368-6

19. Pascal, N., OlivierBasole, K., Claired'Andre, H., \& BocklineOmedo, B. (2021). Risk factors associated with endometritis in zero grazed dairy cows on small holder farms in Rwanda. Preventive veterinary medicine, 188, 105252. Advanceonlinepublication. https://doi.org/10.1016/i.prevetmed.2020.105252

20. Potter et al., 2010 T.J. Potter, J. Guitian, J. Fishwick, P.J. Gordon, I.M. Sheldon Risk factors for clinical endometritis in postpartum dairy cattle Theriogenology, 74 (2010), pp. 127-134. https://doi.org/10.1016/i.theriogenology.2010.01.02320207407

21. Santos, T. M., Gilbert, R. O., \& Bicalho, R. C. (2011). Metagenomic analysis of the uterine bacterial microbiota in healthy andmetritic postpartum dairy cows. Journal of dairy science, 94(1), 291-302. https://doi.org/10.3168/jds.2010-3668

22. Schlegl, Roland \& Drillich, Marc \& Ballas, Panagiotis \& Reinländer, Ulrike \& Iwersen, Michael \& Baumgartner, Walter \& Ehling-Schulz, Monika \& Wagener, Karen. (2020). Field trial on the post-insemination intrauterine treatment of dairy cows with mild endometritis with cephapirin. Theriogenology. 156. https://doi.org/10.1016/j.theriogenology.2020.06.024.

23. Semenov, V \& Baimukanov, D \& Tyurin, V \& Kuznetsov, A \& Tsarevsky, I \& Nikitin, D \& Efimova, I. (2020). Features of adaptation and meat qualities of Aberdeen-Angus bulls on the background of immunostimulation. IOP Conference Series: Earthand Environmental Science. https://doi.org/433.012024.10.1088/1755-1315/433/1/012024.

24. Sheldon, I.M., Noakes, D.E., Rycroft, A.N. and Dobson, H. (2002), Effect of postpartum manual examination of the vagina on uterine bacterial contamination in cows. Veterinary Record, 151: 531-534. https://doi.org/10.1136/vr.151.18.531

25. Stojkov, Yanne\&Keyserlingk, Marina\&Duffield, T. \&Fraser, D.. (2020). Management of cull dairy cows: Cullingdecisions, duration of transport, and effect on cow condition. Journal of DairyScience. https://doi.org/103. 10.3168/jds.2019-17435.

26. System of prevention of gynaecological diseases in high-productive cows under in a farmin the Udmurt Republic Roman Rudakov, Liliya Khamitova, Anastasiya Metlyakova and Vyacheslav Milaev BIO WebConf., 27 (2020) 00094 DOI: https://doi.org/10.1051/bioconf/20202700094

27. Yang, H., Zhang, J., Xue, Z. et al. Potential Pathogenic Bacteria in Seminal Microbiota of Patients with Different Types of Dysspermatism. Sci Rep 10, 6876 (2020). https://doi.org/10.1038/s41598-020-63787-x

Абубакарі Ібрагім Кавла, аспірант, Сумський національний аграрний університет (м. Суми, Україна)

Комплексні методи діагностики та профрілактики послідових ускладнень у коров

Досліди проводили протягом 2018 - 2020 рр. на коровах чорної-рябої породи в умовах ТОВ «Ряснянське» Краснопільського району Сумської області.

Корови були віком 4 - 8 років з середньорічною молочною продуктивністю 2,5 - 3,1 тис.кә молока за лактацію. Оцінку перебігу післяродового періоду проводили згідно із змінами, які відбувалися в статевому апараті самки. При иьому враховували не тільки загальний стан тварин, характер ексудату, розмір та топографрію матки, але й стан яєчників, шийки матки і піхви при ректальному та вагінальному дослідженнях. Діагностику різних форм ендометрита проводили з урахуванням даних анамнезу, клінічного і гінекологічного досліджень.

Для лікування корів дослідної групи з післяродовим ендометритом їм підшкірно ін'єктували 10 мл препарату “Метрісан" в суміші з 0,5 \%-ным розчином новокаӥну з розрахунку 1:1. Інтервал між ін'єкиіями складав 7-10 днів. Кратність залежала від форми ендометрита і складала 3-5 ін'єкцій. Для лікування корів контрольної групи з післяродовим ендометритом їм застосовували 10\%-ный розчин іхтіолу внутриматочно Ін'єкиії 7\%-ного розчину іхтіолу в параректальну клітковину 
В 2018 році в цієї причини вибула 2-корова (1,6 \%), у 2019 році - 4 голови (3,1\%), у 2020 році -4 корови (2,8\%). 3а причинами вікової неплідності в 2018 році вибракували 1 корову (0,8%), 2019 році вибракували 2-корови(1,3\%), 2020 році вибракувано 2 голови (1,4%). За причинами травматизму в 2018 році вибракували 1 корову (0,8 \%), в 2019 році вибракували 1-корова(0,8\%),2020 році вибракували 1-корова голова (0,7%). У 2018 році найпоширенішою патологією післяродового періоду був вульво вагініт 8\%, ендометрит - 6,5 \%, штучно набута неплідність - 0,8 \%. У 2019 році ендометритом хворіло 9,8 \% корів; вагінітом, вульвітом, цервіцитом - 8,3 \%,штучно набута неплідність складала 0,8\%. У 2020 році ендометрит складав 17 \%, вагініт, вульвіт, цервіцит - 9,2 \%, штучно набута неплідність складала-0,8. За результатами досліджень терапевтична ефективність була вищою в дослідній групі, де застосовувалась терапія корів з гострим гнійно-катаральним ендометритом з використанням препарату сепранол та амоксіцилін-150.

Загальна кількість днів неплідності в контрольній групі склала 125 днів, в дослідній - 60 днів. В перерахунку на 1 голову це становить: в контрольній групі - 25 днів, в дослідній -12 днів. Тривалість періоду від родів до запліднення в контрольній групі- 55 днів, в дослідній - 42 дні.

Ключові слова: корови, причини неплідності, післяродовий ендометрит, препарат «Mетрісан»

Дата надходження до редакції: 20.11.2020 p. 